\title{
Personality Trait, Self-Efficacy, and Individual Work Performance on Science Teachers in Indonesia
}

\author{
Zulmi Ramdani* \\ Faculty of Psychology \\ UIN Sunan Gunung Djati Bandung \\ Bandung, Indonesia \\ *zulmiramdani@uinsgd.ac.id
}

\author{
Bagus Hary Prakoso \\ Pusat Asesmen dan Pembelajaran \\ Kementerian Pendidikan dan Kebudayaan RI \\ Jakarta, Indonesia \\ bagus.hary@kemdikbud.go.id
}

\author{
Lidwina Felisima Tae \\ Fakultas Ilmu Pendidikan \\ Universitas Timor \\ Nusa Tenggara Timur, Indonesia \\ lidwinafelisima@unimor.ac.id
}

\author{
Nuchwana Luanganggoon \\ Khon Kaen University \\ Khon Kaen, Thailand \\ nuchwana@kku.ac.th
}

\begin{abstract}
Self-efficacy is regarded as one of the important aspects that could help teachers to achieve their learning goals and optimal work performance. However, in daily practice, there is only limited research that explores the importance of selfefficacy in the education process, especially for science teachers in Indonesia. This research aims to explore the relationship between science teachers' type of personality, self-efficacy, and work performance Indonesia. A total of 123 science teachers were chosen using purposive technique sampling to fill in the questionnaires as a form of self-report. The result shows that the type of personalities such as Extraversion, Conscientiousness, and Openness to Experience significantly correlate to Selfefficacy. In accordance with this result, Self-efficacy also has a positive and significant correlation with the dimension of Task Performance and Contextual Performance. However, Selfefficacy has a negative correlation to the Counterproductive Work Behavior. Therefore, the higher the three personalities possess by a teacher the higher the self-efficacy and the work performance they have. This result asserts that there is a number factor that should be considered by science teachers to achieve the best work performance. The further discussion and the limitation of this research will be explained deeper in this paper.
\end{abstract}

Keywords-contextual performance, counterproductive work behavior, science teachers, self-efficacy, personality trait, task performance

\section{INTRODUCTION}

Teacher's performance is one indicator that could determine whether a teacher is able to provide optimal teaching process for their students at school. To achieve an optimal teaching performance, various preparations, strategies, and planned activities are needed to achieve the best performance. Some factors that should be taken into account by a teacher to achieve the optimization of the performances include the internal factors of the teacher himself, the interactions with other people in the workplace and the facilities provided by the workplace [1,2].

From an environmental point of view, the teachers will always face different organizational climate in their daily teaching process. The school climate will certainly become a factor that determines the optimization of their work [3]. In addition, the relationships built by the teachers and the students also contribute to teachers' readiness in providing teaching and learning process to the students, especially when the teachers feel comfortable with what they have done at school [4]. Another factor that is also considered important related to the personality and individual abilities of the teacher himself. Selfidentity in the form of abilities or skills in teaching which is equipped by positive characters or personalities is the earliest element for the teachers to work optimally $[5,6]$.

Psychological aspects play an important attribute in determining how a teacher can start their activities with the enthusiasm until they give their best performance. Several studies have explained that one of the psychological factors that could contribute to teacher performance is teacher's selfefficacy. Self-efficacy refers to a person's ability to achieve targeted goals and how confident the individual is to achieve these targets $[7,8]$. This attribute plays an important role in giving strength to teachers to be able to give their best performance [9]. In addition, personality factors are also directly related to teachers' self-efficacy and the performance they produce [10].

Previous research has shown that personality has a significant relationship with the performance an individual might achieve [11,12]. Furthermore, a teacher who shows good performance sometimes due to the fact that she/he has the awareness and high confidence in achieving an effective 
learning [13]. However, previous research has not focused much on science teachers, as it tends to be conducted on teachers in general. So that the purpose of this study is to test whether there is a correlation between the dimensions of the Big-Five personality type, self-efficacy, and individual performance of science teachers in Indonesia. The authors hypothesize that there is a significant relationship in the dimensions of the three tested variables.

\section{LITERATURE REVIEW}

\section{A. Big Five Personality}

Big Five Personality is a self-report which has been developed to analyze 5 personality dimensions, namely Extraversion, Agreeableness, Conscientiousness, Neuroticism, and Openness to Experience [14]. Big Five Personality has been widely translated into many languages and tested for validity by many researchers from various countries. A study by Schmitt [15] has translated the Big Five Personality into 28 languages and distributed it to a total of 17,837 subjects for further study. This study found that the dimensions of Big Five Personality are robust or stand alone and have a good level of validity.

In more detail, the dimensions of personality in the Big Five Personality are described as follows [16-18]. The Extraversion dimension relates to the tendency and the comfort of an individual to interact with others which is marked by the individual's flexibility to socialize with other people. The Agreeableness dimension allows an individual to avoid conflict and tends to help other people. While the dimension of Conscientiousness owned by an individual who is cautious and full of consideration in making the decision. The dimension of Neuroticism is owned by a person with good emotional stability where the individual is able to withstand the pressure or stress. Finally, the dimension of Openness to Experience belongs to individual who is always interested in learning new things which makes them to become more creative and imaginative [14]. Furthermore, Cobb-Clark and Schurer [19] also found that Big-Five personality characteristics are stable at working/productive age and there are no significant changes in personality due to age changes.

\section{B. Self-Efficacy}

Self-efficacy relates to how an individual assesses his or her own ability to complete a given task [20]. If it is connected to the realm of education, then it could be said that teacher's selfefficacy indicates the level of confidence a teacher has towards his ability to design, execute and evaluate the teaching activities [21]. Teachers' self-efficacy can determine the effectiveness of his pedagogical skills that is related to the teaching skills [22]. Furthermore, self-efficacy can also influence how a teacher sets the learning goals [23], makes the innovation in teaching strategies [24] and chooses appropriate teaching methods that suit the students' characteristics [25].

When self-efficacy is connected to other competencies, it can also determine the positive attitudes owned by the teachers
[21] including the teachers' social skills in interacting with students and other social relationships within the school environment [26]. In the end, the level of teacher's selfefficiency can influence the level of job satisfaction and the likelihood of a teacher to pursue his profession as a teacher $[27,28]$.

\section{Individual Work Performance}

Individual work performance is related to the performance or the quality of work that an individual show in his job [29]. Based on a literature study conducted by Piccolo et al. [30], they found that individual work performance has a close relationship with job satisfaction which is characterized by a high and consistent correlation value. In addition to dealing with job satisfaction, individual work performance is also closely related to individual's multidimensional behavior. This shows that each individual is different in personality, cognitive abilities and learning experiences which in turn will affect knowledge, skills and work habits that can mediate personality and cognitive abilities on work performance [31]. This finding was also confirmed by Ramdani et al. [29] who found that individual work performance is also determined by the individual's skill level.

Furthermore, individual work performance is also greatly influenced by the work environment and work atmosphere such as organizational hierarchical levels, organizational boundaries, physical boundaries, and the process of providing and distributing the information within the organization [32]. The importance of effective atmosphere at work is further investigated by $\mathrm{Ng}$ and Feldman [33], who found a positive relationship between conflict at work and individual performance where the conflict at work can have a direct effect on the quality of an individual's work.

\section{Correlation between Variables}

Many studies have investigated the relationship between the Big Five Personality, job performance and several other related variables. Van Dierendonck [34] have examined the relationship between the dimensions of Big Five Personality and three job performance criteria (job proficiency, training proficiency, and personnel data) for several types of work. They found that the Conscientiousness dimension showed a consistent relationship with all job performance criteria for all job groups. Furthermore, they found that Extraversion was a valid predictor for two types of work that involve social interaction such as manager and sales. In addition, the dimensions of Openness to Experience and Extraversion are the valid predictors for Training Proficiency criteria. Furthermore, Maksić and Pavlović [35] also found that personality dimensions (Extraversion and Neuroticism) and certain learning styles (Reflector and Pragmatist) were statistically significant as the predictors of job performance levels. This shows that the personality variable of an individual is responsible for measuring work performance.

A study by An and Carr [11] has also attempted to relate how other moderating variables can moderate the relationship 
between Big Five Personality dimensions and individual job performance. They found that Autonomy acts as a moderator variable between personality dimensions in Big Five Personality and job performance levels. Statistically, this study shows that the validity of Conscientiousness and Extraversion is greater in the work of managers with high autonomous values. Meanwhile, the validity of Agreeableness also shows a high score in jobs with high autonomy compared to jobs with low autonomy but with a negative correlation value.

Talking further, in relationship with the variable of selfefficacy, Van Uden et al. [26] found an influence on individual work performance. In this study, they tried to see the relationship between individual-level knowledge sharing (such as attitudes, profit estimates, self-efficacy, and actualization of behavior) and individual work performance. The results of the study confirmed the hypothesis that knowledge-sharing behavior, which includes self-efficacy variable, also affects individual performance.

\section{METHODS}

This study uses a correlational quantitative approach in which the researchers look for the relationship between each variable being tested. There are 3 variables tested in this study, namely personality traits, self-efficacy, and individual work performance.

\section{A. Sample}

Respondents were selected using purposive sampling technique. The number of respondents involved in this study was 123 people who have the characteristics of being a science teacher at the elementary, junior and senior high school levels.

\section{B. Instruments}

This study used 3 instruments in the form of a psychological scale that measures 3 tested variables. The first instrument is the TIPI-Indonesia which measures a person's typical personality. The TIPI-Indonesia consists of 10 items that measure personality type, namely Extroversion, Agreeableness, Conscientiousness, Emotional Stability and Openness [36]. The test-retest reliability value for each of these personality types moved from .71 to .85 . The second instrument used in this study was STEBI (Science Teaching Efficacy Beliefs Instrument) which measures science teacher's self-efficacy. The STEBI used in this study was developed by Tae et al. [37] with a total of 15 items. The 15 items were used to measure self-efficacy in science teachers which consists of four major components including positive pedagogical in motivating students (4 items), coping with changes and challenges ( 4 items), teacher's perception on ideal pedagogy ( 3 items), and enthusiasm (4 items). Meanwhile, the third instrument used in this study was the Individual Work Performance (IWP) questionnaire developed by Ramdani et al. [29] with a total of 40 items. The IWP scale measures teacher performance attributes which include task performance, contextual performance and counterproductive work behavior. when the structural equation modeling was tested, the reliability value for each aspect on the IWP scale moved from a score of $.8-.93$ with a loading factor value of more than .5 [29]. Thus it can be concluded that the use of these three instruments has fulfilled good psychometric properties.

\section{Collecting and Analysing Data}

Data was collected using the online media of Google Form, where the researchers first validating the instruments displayed in the Google Form. Questionnaires were distributed to respondents according to predetermined characteristics. Data was collected for 1 month in February 2020. The data obtained were then tabulated and analyzed using SPSS.

\section{RESULTS AND DISCUSSIONS}

First of all, the description of the respondents involved in the study is explained. A total of 123 respondents were involved in the study (see table 1)

TABLE I. DEMOGRAPHIC FEATURES OF RESPONDENTS

\begin{tabular}{|c|c|c|c|}
\hline No. & Category & $\mathbf{N}$ & Percentage (\%) \\
\hline \multirow[t]{3}{*}{1} & SEX & & \\
\hline & Male & 45 & 36.6 \\
\hline & Female & 78 & 63.4 \\
\hline \multirow[t]{4}{*}{2} & TYPE OF SCHOOL & & \\
\hline & Public & 63 & 51.2 \\
\hline & Private & 59 & 48 \\
\hline & Public-Private & 1 & .8 \\
\hline \multirow[t]{3}{*}{3} & EDUCATIONAL BACKGROUND & & \\
\hline & S1 (Bachelor Degree) & 106 & 86.2 \\
\hline & S2 (Master Degree) & 17 & 13.8 \\
\hline \multirow[t]{4}{*}{4} & LEVEL OF SCHOOL & & \\
\hline & Elementary School & 9 & 7.4 \\
\hline & Junior High School & 63 & 51.2 \\
\hline & Senior High School & 51 & 41.4 \\
\hline \multirow[t]{5}{*}{5} & TEACHING SUBJECT & & \\
\hline & Biology & 23 & 18.7 \\
\hline & Chemistry & 23 & 18.7 \\
\hline & Physics & 22 & 17.8 \\
\hline & Integrated Science & 55 & 45.8 \\
\hline
\end{tabular}

The information presented in table 1 illustrates the demographic differences among the respondents involved in this study. For the educational background, respondents were dominated by bachelor degree graduate (S-1) which reached $86.2 \%$ (106 people). Meanwhile, for the level of school, the proportion of teachers teaching at the elementary level accounted for the smallest number, namely only 9 teachers. Next, the reliability coefficient will be explained further in table 2 . 
TABLE II. RELIABILITY COEFFICIENTS OF SCALE

\begin{tabular}{|c|l|c|}
\hline No. & \multicolumn{1}{|c|}{ Variable } & Scores (r) \\
\hline 1 & Personality Traits & .524 \\
\hline 2 & Self-Efficacy & .795 \\
\hline 3 & Task Performance & .937 \\
\hline 4 & Contextual Performance & .915 \\
\hline 5 & Counterproductive Work Behavior & .732 \\
\hline
\end{tabular}

Note. All reliability coefficients are acceptable

Table 2 explains that the reliability coefficient obtained for each variable moved from a score of .5 to .9 . Theoretically, the reliability coefficient that reaches more than .7 indicates that the instrument used in this study is reliable.
TABLE III ITEM DISCRIMINATION OF SCALE

\begin{tabular}{|c|l|c|}
\hline No. & \multicolumn{1}{|c|}{ Variable } & Range of Scores \\
\hline 1 & Personality Traits & $.005-.378$ \\
\hline 2 & Self-Efficacy & $.267-.587$ \\
\hline 3 & Task Performance & $.511-.732$ \\
\hline 4 & Contextual Performance & $.479-.771$ \\
\hline 5 & Counterproductive Work Behavior & $.179-.609$ \\
\hline
\end{tabular}

In table 3, each scale used shows the various value of difference power. The difference power obtained by various items in the instrument used in this research reaches more than .3. Furthermore, table 4 displays in more detail about the correlation produced by each variable.

TABLE IV. CORRELATION BETWEEN VARIABLES

\begin{tabular}{|c|c|c|c|c|c|c|c|c|}
\hline Variable & 2 & 3 & 4 & 5 & 6 & 7 & 8 & 9 \\
\hline Extraversion (1) & $-.178^{\prime}$ & .130 & -.028 & $.187^{\prime}$ & $.262 "$ & .108 & .093 & .041 \\
\hline Agreeableness (2) & 1 & $.197^{\prime}$ & $.351 "$ & .173 & .070 & .028 & -.052 & $-.202^{\prime}$ \\
\hline Conscientiousness (3) & & 1 & $.337^{\prime \prime}$ & $.361 "$ & $.365^{\prime \prime}$ & $.335^{\prime \prime}$ & $.260 "$ & $-.195^{\prime}$ \\
\hline Emotional Stability (4) & & & 1 & $.252 "$ & .112 & .055 & .020 & $-.330^{\prime \prime}$ \\
\hline Openness to Experience (5) & & & & 1 & $.348^{\prime \prime}$ & .173 & $.290 "$ & -.081 \\
\hline Self-Efficacy (6) & & & & & 1 & $.671 "$ & $.586 "$ & $-.212^{\prime}$ \\
\hline Task Performance (7) & & & & & & 1 & $.778^{\prime}$ & $-.188^{\prime}$ \\
\hline Contextual Performance (8) & & & & & & & 1 & -.078 \\
\hline Counterproductive Work Behavior (9) & & & & & & & & 1 \\
\hline
\end{tabular}

Note. ${ }^{*} P<.05,{ }^{* *} P<.01$

Table 4 displays the correlation results obtained from the test of each research variable. The result of the study generally shows that the measuring instruments used in this study can be accounted for psychometrically. This can be clearly seen from the results of the reliability and the difference power obtained by the three variables that meet the criteria of good psychometrics [38]. Based on the information obtained in table 4 , it can be concluded that the correlation generated by each variable varies widely. A positive and significant correlation is indicated by a correlation coefficient that scored more than .3 . If the correlation between these variables is more than .3, then it can be said that there is a positive relationship between the variables tested [39]. In table 4, the correlations generated by Big Five Personality dimensions produce varied coefficients. There are three personality types that are positively and significantly correlated with the self-efficacy variable, namely Extraversion (.262), Conscientiousness (.365) and Openness to Experience (.348), while the other 2 personality types show weak and insignificant correlation results (Agreeableness = $.070 \&$ Emotional Stability $=.112$ ). Thus it can be concluded that the higher the three personality types, the higher the selfefficacy of the science teacher.

The high and significant relationship between personality types and self-efficacy is supported by several previous studies which also agreed to state this relationship. Chien and $\mathrm{Wu}$ [40] in their study explained that Conscientiousness is related to teacher's self-efficacy. In the same vein, Djigić et al. [10] also stated that Conscientiousness and Openness to Experience are the best predictors for determining the teacher's self-efficacy. Meanwhile, other research also shows that since types of personality has a strong correlation with self-efficacy, the intervention program to increase teacher's self-efficacy should consider the variable of teacher's personality types [41].

Furthermore, among the five personality types tested in this study, there is only one personality type that has a high, positive and significant correlation with task performance, namely the Conscientiousness personality type $(r=.335)$. These results provide a specific description of this study where the personality type of Conscientiousness is directly related to two other variables, namely self-efficacy and task performance [42]. From table 4, it also can be seen the results related to the existing correlation where self-efficacy has a very strong and significant relationship with the dimensions of task performance $(r=.671)$ and contextual performance $(r=.568)$. The results of this correlation indicate that the higher the selfefficacy of the science teacher, the higher the task performance and contextual performance of the teacher. Previous research has also shown the same results, where self-efficacy is an important variable in determining teacher's work performance including their technical ability to do the tasks [13]. Selfefficacy could also influence teacher's performance [43] and the way the teacher transfer the knowledge to the students [44]. 
This study provides comprehensive information about the factors that the science teachers should be taken into account in conducting the teaching and learning in schools. Of course, the psychological attributes described earlier must be tested further by involving a more complex model to ascertain to what extent each existing variables influence each other. In addition, this study also focuses on science teachers in Indonesia who, in essence, have significant differences with other teachers with different backgrounds and expertise, thus the future further research is needed in terms of these differences.

\section{CONCLUSION}

This research concludes that there is a significant relationship between three tested variables on science teachers. If a science teacher has high scores on the personality of extraversion, conscientiousness and openness to experience then it means that he/she also has high self-efficacy. The higher the self-efficacy, the higher the performance on science teacher.

\section{ACKNOWLEDGMENT}

This study is the result of a routine collaboration initiated by the Center for Assessment and Learning, the Ministry of Education and Culture of Indonesia with the Faculty of Psychology, UIN Sunan Gunung Djati Bandung and the Faculty of Education, University of Timor, East Nusa Tenggara Province. We would like to thank all the respondents who have involved in this research.

\section{REFERENCES}

[1] A. Alevriadou and K. Pavlidou, "Teachers' beliefs about the factors affecting the positive outcome of intervention in managing challenging behaviors of individuals with intellectual disabilities," Procedia - Soc. Behav. Sci., vol. 159, pp. 132-136, 2014.

[2] L.J. Graham, S.L.J. White, K. Cologon, and R.C. Pianta, "Do teachers' years of experience make a difference in the quality of teaching?," Teach. Teach. Educ., vol. 96, p. 103190, 2020

[3] S. Treputtharat and S. Tayiam, "School climate affecting job satisfaction of teachers in primary education, Khon Kaen, Thailand," Procedia - Soc. Behav. Sci., vol. 116, pp. 996-1000, 2014.

[4] M. Md. Yunus, W.S.W. Osman, and N.M. Ishak, "Teacher-student relationship factor affecting motivation and academic achievement in ESL classroom," Procedia - Soc. Behav. Sci., vol. 15, pp. 2637-2641, 2011.

[5] R. Bauwens, J. Muylaert, E. Clarysse, M. Audenaert, and A. Decramer, "Teachers' acceptance and use of digital learning environments after hours: Implications for work-life balance and the role of integration preference," Comput. Human Behav., vol. 112, no. July, p. 106479 , 2020.

[6] B. Naoreen, H. Gull, F. Asghar, and A. Mahmood, "Gender wise comparison of trained and untrained teachers' performance on students' learning achievement in mathematics," Procedia - Soc. Behav. Sci., vol. 116, pp. 3016-3020, 2014

[7] A. Bandura, Self-Efficacy: The Exercise of Control. Worth Publishers, 1997.

[8] S.N. Rodda, N. Booth, M. Vacaru, B. Knaebe, and D.C. Hodgins, "Behaviour change strategies for internet, pornography and gaming addiction: A taxonomy and content analysis of professional and consumer websites," Comput. Human Behav., vol. 84, pp. 467-476 2018.

[9] B. Ghonsooly, G.H. Khajavy, and F.M. Mahjoobi, "Self-efficacy and Metacognition as Predictors of Iranian Teacher Trainees' Academic Performance: A Path Analysis Approach,” Procedia - Soc. Behav. Sci., vol. 98, pp. 590-598, 2014.

[10] G. Djigić, S. Stojiljković, and M. Dosković, "Basic Personality Dimensions and Teachers' Self-efficacy," Procedia - Soc. Behav. Sci., vol. 112, no. Iceepsy 2013, pp. 593-602, 2014.

[11] D. An and M. Carr, "Learning styles theory fails to explain learning and achievement: Recommendations for alternative approaches," Pers. Individ. Dif., vol. 116, pp. 410-416, 2017.

[12] Z. Ramdani, S. Amrullah, and L. Felisima Tae, "Pentingnya Kolaboras dalam Menciptakan Sistem Pendidikan yang Berkualitas," MediaPSI, vol. 5, no. 1, pp. 40-48, 2019

[13] S. Tanyer, "The Role of Writing and Reading Self-efficacy in First-year Preservice EFL Teachers' Writing Performance," Procedia - Soc. Behav. Sci., vol. 199, pp. 38-43, 2015.

[14] J.M. Digman, "Personality structure: Emergence of the five-factor model," Annu. Rev. Psychol., vol. 41, pp. 417-440, 1990.

[15] D.P. Schmitt, "The geographic distribution of Big Five personality traits: Patterns and profiles of human self-description across 56 nations," J. Cross. Cult. Psychol., vol. 38, no. 2, pp. 173-212, 2007.

[16] C. Montag, C. Sindermann, D. Lester, and K.L. Davis, "Linking individual differences in satisfaction with each of Maslow's needs to the Big Five personality traits and Panksepp's primary emotional systems," Heliyon, vol. 6, no. 7, p. e04325, 2020

[17] B.T. Nystrand, S.O. Olsen, and A.A. Tudoran, "Individual differences in functional food consumption: The role of time perspective and the Big Five personality traits," Appetite, vol. 156, no. September 2020, 2021.

[18] W. Waleriańczyk and M. Stolarski, "Personality and sport performance: The role of perfectionism, Big Five traits, and anticipated performance in predicting the results of distance running competitions," Pers. Individ. Dif., no. March, p. 109993, 2020.

[19] D.A. Cobb-Clark and S. Schurer, "The stability of big-five personality traits," Econ. Lett., vol. 115, no. 1, pp. 11-15, 2012.

[20] A. Bandura, "Self-efficacy mechanism in human agency," Am. Psychol., vol. 37, no. 2, pp. 122-147, 1982, doi: 10.1037/0003-066X.37.2.122.

[21] Y.M. Huang, O.O. Shiyanbola, and H.Y. Chan, "A path model linking health literacy, medication self-efficacy, medication adherence, and glycemic control," Patient Educ. Couns., vol. 101, no. 11, pp. 19061913, 2018

[22] L.P. Maricuțoiu and C. Sulea, "Evolution of self-efficacy, student engagement and student burnout during a semester. A multileve structural equation modeling approach,” Learn. Individ. Differ., vol. 76, no. February, 2019.

[23] I. Burić and A. Moè, "What makes teachers enthusiastic: The interplay of positive affect, self-efficacy and job satisfaction," Teach. Teach. Educ., vol. 89, 2020.

[24] R. Van Gasse, K. Vanlommel, J. Vanhoof, and P. Van Petegem, "Teacher interactions in taking action upon pupil learning outcome data: A matter of attitude and self-efficacy?," Teach. Teach. Educ., vol. 89, p. 102989,2020

[25] R.M. Allinder, "An examination of the relationship between teacher efficacy and curriculum-based measurement and student achievement," Remedial Spec. Educ., vol. 16, no. 4, pp. 247-254, 1995.

[26] J.M. Van Uden, H. Ritzen, and J.M. Pieters, "I think i can engage my students. Teachers' perceptions of student engagement and their beliefs about being a teacher," Teach. Teach. Educ., vol. 32, pp. 43-54, 2013.

[27] H.N. Perera and J.E. John, "Teachers' self-efficacy beliefs for teaching math: Relations with teacher and student outcomes," Contemp. Educ. Psychol., vol. 61, p. 101, 2020. 
[28] E.M. Skaalvik and S. Skaalvik, "Teacher self-efficacy and teacher burnout: A study of relations," Teach. Teach. Educ., vol. 26, no. 4, pp. 1059-1069, 2010.

[29] Z. Ramdani, R. Marliani, and A.A. Rahman, "The individual work perfomance scale: A psychometric study and its aplication for emloyee performance," in Humanities \& Social Sciences Reviews, vol. 7, no. 5, 2019, pp. 405-414.

[30] R. Piccolo, R. Greenbaum, D. Hartog, and R. Folger, "The relationship between ethical leadership and core job characteristics," J. Organ. Behav., vol. 31, pp. 259-278, 2010.

[31] J. Nakamura and M. Dubin, Flow in motivational psychology, Second Edi., vol. 9. Elsevier, 2015.

[32] E.M. Cummings and P. Davies, "Emotional security as a regulatory process in normal development and the development of psychopathology," Dev. Psychopathol., vol. 8, pp. 123-139, 1996.

[33] T.W.H. Ng and D.C. Feldman, "Employee age and health," J. Vocat. Behav., vol. 83, no. 3, pp. 336-345, 2013.

[34] D. van Dierendonck, "The construct validity of Ryff's Scales of Psychological Well-being and its extension with spiritual well-being," Pers. Individ. Dif., vol. 36, no. 3, pp. 629-643, 2004.

[35] S. Maksić and J. Pavlović, "Educational researchers' personal explicit theories on creativity and its development: A qualitative study," High Abil. Stud., vol. 22, no. 2, pp. 219-231, 2011.

[36] H. Akhtar, "Translation and validation of the Ten-Item Personality Inventory (TIPI) into Bahasa Indonesia," Int. J. Res. Stud. Psychol., vol. 7, no. 2, pp. 59-69, 2018.

[37] L.F. Tae, Z. Ramdani, G.A. Shidiq, S. Amrullah, and B.H. Prakoso, "The adaptation of language and culture for science teaching efficacy belief instrument (Stebi) in Indonesian context," in 2nd International Conference on Educational Assessment and Policy (ICEAP 2019) THE, 2019, no. December, pp. 55-63.

[38] Z. Ramdani, "Construction of academic integrity scale," Int. J. Res. Stud. Psychol., vol. 7, no. 1, pp. 87-97, 2018.

[39] D.F. Salsabila, R. Rofifah, Y. Natanael, and Z. Ramdani, "Uji Validitas Konstruk Indonesian-Psychological Measurement of Islamic Religiousness (I-PMIR)," J. Psikol. Islam dan Budaya, vol. 2, no. 2, pp. $1-10,2019$.

[40] M. Saberi and A. Rahimi, "On the effect of personality and efficacy on second language instructors' performance," Procedia - Soc. Behav. Sci., vol. 136, pp. 240-245, 2014.

[41] C. Marr, E. Vaportzis, M. Dewar, and A.J. Gow, "Investigating associations between personality and the efficacy of interventions for cognitive ageing: A systematic review," Arch. Gerontol. Geriatr., vol. 87, no. May 2019, p. 103992, 2020.

[42] S.C. He, "Interactive effects of corticotropin-releasing hormone receptor 1 gene and work stress on burnout in medical professionals in a Chinese Han population,” J. Affect. Disord., vol. 252, no. December 2018.

[43] N. Alagözlü, "Pre-service EFL Teachers $\square$ Professional Self-concept: English Teaching Efficacy, Self Reported English Proficiency and Pedagogical Strategies: A Case Study in Turkish Context," Procedia Soc. Behav. Sci., vol. 232, no. April, pp. 196-200, 2016.

[44] S.P. Chien and H.K. Wu, "Examining influences of science teachers' practices and beliefs about technology-based assessment on students' performances: A hierarchical linear modeling approach," Comput. Educ., vol. 157, no. July, p. 103986, 2020. 